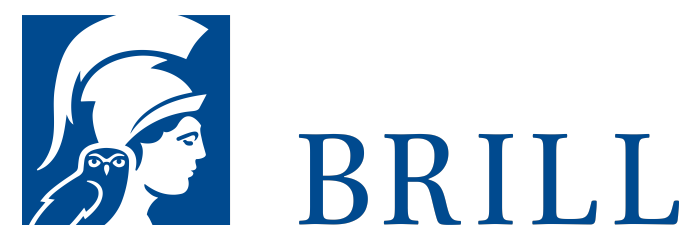

\title{
Selbstbewusst ins Leben
}

Kinder und Jugendliche stärken, fördern, motivieren

Author: Petra Buchwald

In einer modernen Welt voller Anforderungen, Gefahren und Probleme müssen Kinder lernen, sich selbst zu behaupten. Das beste Rüstzeug, das wir ihnen mitgeben können, ist ein starkes Ich, ein starkes Selbstbewusstsein. Nur so werden sie Verführungen - von Alkohol über Computerspiele bis zu falschen Freundeskreisen - trotzen und ihren eigenen Weg unbeirrt gehen können. Mit Hilfe dieses Ratgebers können Eltern und Lehrer Kindern und Jugendlichen helfen, ein starkes Ich und eine positive Lebenseinstellung zu entwickeln. Anhand zahlreicher Übungen lernen Heranwachsende, richtige Entscheidungen zu treffen, sich realistische Ziele zu setzen und Probleme selbst in den Griff zu bekommen - so wird Ihr Kind Schritt für Schritt kooperativ, konfliktfähig und selbstbewusst!

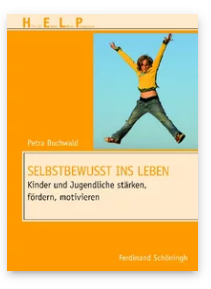

Pages: 112 Seiten

Language:

German

Subjects:

General,

Education

Publisher: Brill |

Schöningh

Series:

HELP - Hilfe für

Eltern, Lehrer,

Pädagogen

E-Book (PDF)

Released online: 3o Dec 2019

ISBN: 978-3-

657-77635-1

List price

Paperback

Publication date: 10 Sep 2012

ISBN: 978-3506-77635-8

List price 
Petra Buchwald, Diplom-Pädagogin, Dr. phil., ist Professorin an der Bergischen Universität Wuppertal im Institut für Bildungsforschung und der School of Education. Seit 2008 ist sie Präsidentin der Internationalen Stress-Gesellschaft.

For more information see brill.com

\begin{abstract}
Order information: Order online at brill.com +44330 333 0049 | customerservices@brill.com Submission information: brill.com/authors
\end{abstract}

Titles published by Brill | Fink, Brill | mentis or Brill | Schöningh: +49(o)71 5413279216 | brill@brocom.de 